\title{
Eötvös Lóránd Physical Society, Hungary
}

\author{
President : G. Szigeti \\ Secretary-General : I. Kovács \\ Headquarters address : \\ Szabadságtér 17 \\ Budapest V.
}

This article on the Hungarian Physical Society is taken from information supplied by $\mathrm{G}$. Turchanyi.
The Hungarian Physical Society is named after its founder Lóránd Eötvös who lived from 1848 to 1919 . He was one of the most distinguished of Hungarian physicists. Among his major achievements were the demonstration of the proportionality of weight and mass using the ingenious Eötvös torsion balance, and his measurement of the temperature dependence of surface tension (giving the Eötvös constant). He founded the Physical Society in 1891.

The Society is a voluntary association of Hungarian physicists and others engaged in physics. Its purposes are to:

a) foster and develop physical research ;

b) improve and assist the teaching of physics ;

c) improve the standards of general physical knowledge ;

d) promote the application of physics in every field ;

e) raise and discuss theoretical, organizational and ideological questions connected with physics and physics teaching ;

f) promote general appreciation of the physicist's vocation and work.

The governing body of the Society is the Presidium elected by a General Assembly. The Presidium is charged with managing the affairs of the Society and directing its activities.
During periods between General Assemblies, a Steering Committee, also elected by the General Assembly, is authorized to pass important resolutions. The everyday work of the Society, which has nearly a thousand members, is directed by this $73 \mathrm{mem}$ ber Steering Committee.

Further education in physics for members of the Society is implemented by meetings held at the headquarters, where Hungarian or other specialists deliver lectures on the various branches of science or particular scientific problems, or give comprehensive reports on the most upto-date fields which initiate debates of wide scope.

Society members also participate in meetings held to discuss recently published books. Conferences, Summer Schools, and Group Studies on particular subjects, play an important role in the training of specialized physicists in Hungary and in furthering international relations. The number of visitors from abroad to the recent International Conferences held by the Society was considerable, rising to nearly five hundred on several occasions. Most of the Conferences are held in co-operation with the Department of Mathematics and Physics of the Hungarian Academy of Sciences.

Some of the activities of the Society

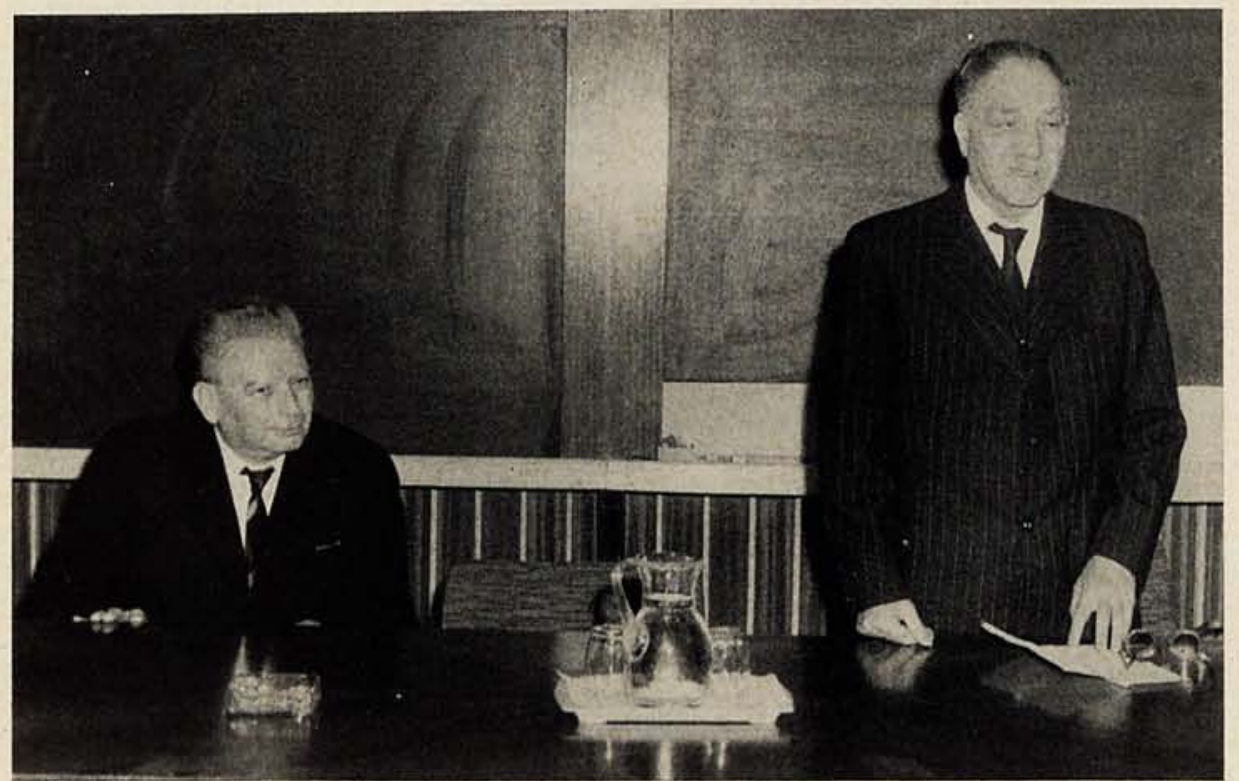

in 1969 are given in the following list of events :

16 April : Commemorative meeting at Budapest on the 50th anniversary of the death of Lóránd Eötvös

April : Four-day meeting and exhibition for schoolteachers at Szeged

April and October: Two-week course in vacuum physics

22-26 May: Four-day conference at Balatonvilágos on plasma physics and its applications

June: Two-week summer school at Keszthely on nuclear physics

17-21 June: Five-day colloquium at Tihany on applications of the Mössbauer effect

20 August : Society Itinerary Congress at Miskole

24 August: International conference on cosmic radiation at Budapest (under the auspices of IUPAP).

The membership of the Society includes a considerable number of secondary school physics teachers and of university physics staff. Thus the Society, through these members, has a decisive influence on all physics teaching in Hungary. This part of the membership has formed a secondary school committee and has an effective say on the instruction in physics by reviewing textbooks, curricula and plans for university tuition, and by open discussion of these subjects.

The journal of the Society is Fizikai Szemle, the Physical Review. With articles of wide scope and high standard, it serves the purpose of further education in physics presenting subjects taken from the entire field of physics. The Review advertises events concerning the membership and the life of the Society as a whole. In addition, it informs Hungarian physicists, both at home and abroad, about recent Hungarian attainments in physics.

The Society has arrangements with the Physical Societies of Czechoslovakia, Poland, the German Democratic Republic and Bulgaria for organizing conferences and exchange visits.

G. Szigeti (left), President of the Eötvös Lóránd Physical Society, at a meeting with the previous President the late Z. Gyulai. 